\title{
CARRIER TRAPS AS TRANSPORT STATES IN BULK-HETEROJUNCTION P3HT:PCBM STRUCTURES FOR SOLAR PHOTOVOLTAICS
}

\author{
V. Kažukauskas ${ }^{\mathrm{a}}$, M. Pranaitis ${ }^{\mathrm{a}}$, A. Arlauskas ${ }^{\mathrm{a}}$, M. Glatthaar ${ }^{\mathrm{b}}$, and A. Hinsch ${ }^{\mathrm{b}}$ \\ ${ }^{a}$ Semiconductor Physics Department and Institute of Materials Science and Applied Research, Vilnius University, \\ Saulètekio 9, LT-10222 Vilnius, Lithuania \\ E-mail: vaidotas.kazukauskas@ff.vu.lt \\ ${ }^{\mathrm{b}}$ Fraunhofer Institute for Solar Energy, Freiburg, Germany
}

Received 17 April 2009; revised 16 June 2009; accepted 18 June 2009

\begin{abstract}
We report the investigation of carrier transport as affected by trapping states in blends of poly-3-hexylthiophene (P3HT) with the fullerene derivative [6,6]-phenyl-C61-butyric acid methyl ester (PCBM) that are promising materials for the organic solar cell development. Devices have been fabricated from P3HT:PCBM blends with 6:5 wt. ratio in the inverted layer configuration. Their solar efficiency is $3.7 \%$ and the fill factor of the current-voltage dependences is up to $68 \%$. We demonstrate that, despite such relatively good macroscopic parameters, the carrier trapping is effectively involved in transport phenomena. The results have been analysed numerically by taking into account the carrier thermal generation from traps as well as the mobility variation according to the Gaussian disorder model. Mobility parameters obtained by both methods demonstrate good coincidence. The evaluated density of trapping states is up to $10^{20}-7 \cdot 10^{21} \mathrm{~cm}^{-3}$ and their activation energy is about $0.18 \mathrm{eV}$. At such a high density these relatively shallow states could presumably act as transport states, limiting the carrier mobility.
\end{abstract}

Keywords: organic solar cells, inverted layer sequence, efficiency, carrier trapping, mobility

PACS: 73.50.-h, 73.61.Ph, 85.60.Bt

\section{Introduction}

Carrier transport properties are essential in the photonic organic material engineering and device development as they determine macroscopic material parameters and therefore limit the device functionality and efficiency. Charge carrier mobility is one of the main factors conditioning the carrier transport in organic materials which are naturally highly disordered $[1,2]$. On the other hand, in organic materials the mobility itself (at least of one type of carriers) is often limited by a severe carrier trapping. The evidence of charge trapping effects in the bulk-heterojunction solar cells fabricated from the blends of poly[2-methoxy-5-(3',7'dimethyloctyloxy)-1,4-phenylene vinylene] (MDMOPPV) and methano-fullerene[6,6]-phenyl $\mathrm{C}_{61}$-butyric acid methyl ester ([60] PCBM) was demonstrated in [3], depending on the applied bias. Carrier trapping was evidenced not only in material blends and organic devices on their basis [2-5], but in single layer samples as well (e. g., [6]), proving that the carrier trapping is an internal feature of organic materials. This results in an imbalance of different carrier flows, and therefore, to elim- inate the problem, specific technological solutions have to be found. Consequently, fundamental investigations of complex carrier transport phenomena are challenging and practically important tasks. In this presentation the carrier transport and trapping effects will be analysed in blends of P3HT with PCBM that are of particular importance for the development of solar cells.

\section{Samples and experiment}

We investigated organic solar cell devices produced in the so-called inverted layer sequence based on P3HT:PCBM blend bulk-heterojunction (Fig. 1). The inverted layer sequence structures offer some practical advantages as compared to the devices of conventional set-up [7]. Their layout is presented in Fig. 2. The devices were fabricated on cleaned floatglass. A $80 \mathrm{~nm}$ thick Al layer was thermally evaporated on the substrate, then a Ti layer of $20 \mathrm{~nm}$ was evaporated upon it by electron-beam heating, both in vacuum better than $10^{-5}$ mbar. Titanium forms the electron contact, while the Al layer is used to assure a high sheet conductance of 

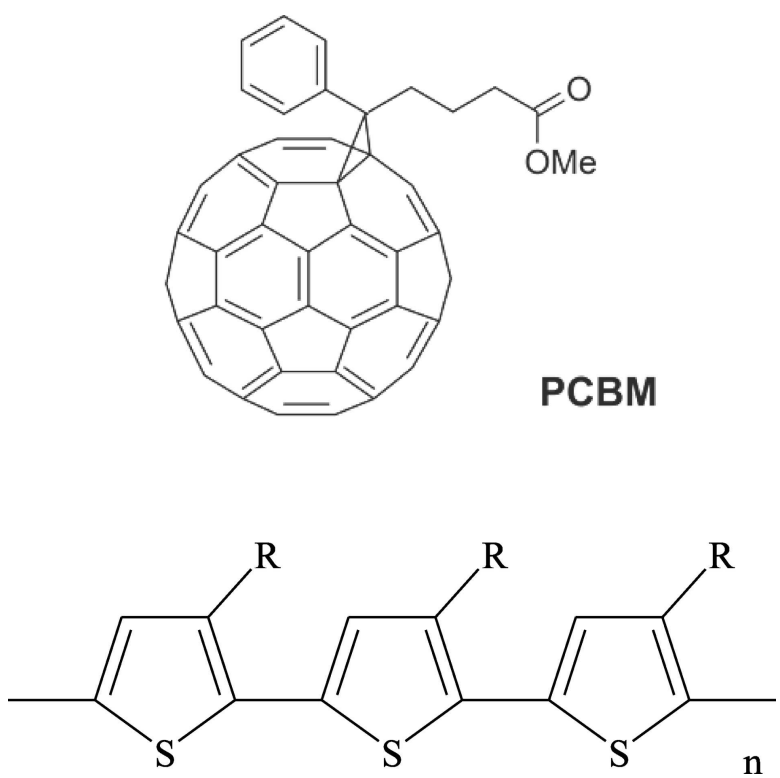

Fig. 1. Structures of the blend constituents PCBM and P3HT $(\mathrm{R}=$ $\mathrm{C}_{6} \mathrm{H}_{13}$ ).
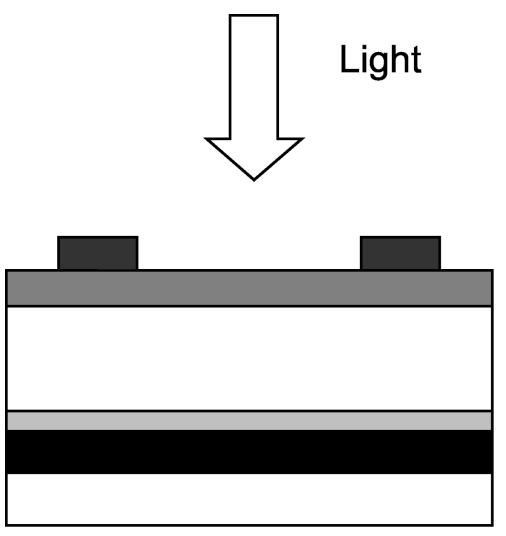

Metal grid PEDOT:PSS

Active layer

Titanium

Aluminium

Substrate

Fig. 2. Schematic layout of the inverted device structure.

the electrode. After that the photoactive P3HT:PCBM layer with the 6:5 weight ratio was spincoated from $\sim 2 \%$ wt. tetralin solution. Its thickness was about 200 or $350 \mathrm{~nm}$. PEDOT:PSS layer with thickness of $200 \mathrm{~nm}$ was spincoated upon the active layer as a hole contact. Finally, to support its sheet conductance a gold grid was evaporated on top with a finger width of $100 \mu \mathrm{m}$ and a distance between the fingers of $500 \mu \mathrm{m}$. After the preparation the samples have been annealed for $10 \mathrm{~min}$ at $100^{\circ} \mathrm{C}$.

Current-voltage $(I V)$ characterization was used to investigate carrier injection properties. For the $I V$ measurements the voltage step was less than $0.1 \mathrm{~V}$ and the duration of the step was long enough to assure the current stabilization between readouts. To prevent the sample polarization by voltage, the $I V$ measurements were always started from $0 \mathrm{~V}$.

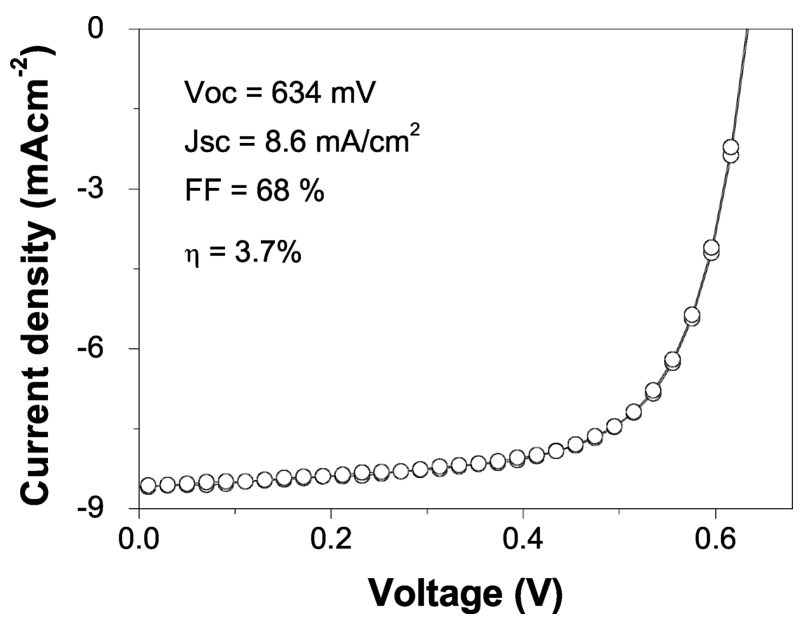

Fig. 3. Current-voltage dependence of the device upon illumination by AM 1.5 spectrum light with $100 \mathrm{~mW} / \mathrm{cm}^{2}$ power density.

Carrier traps were analysed by the Thermally Stimulated Current (TSC) spectroscopy [6]. For the TSC measurements the unexcited samples were cooled down to liquid nitrogen temperature. Later on they were excited for 10 min by the white light from a $100 \mathrm{~W}$ halogen lamp. After that the excited samples were heated at a constant rate of $10 \mathrm{~K} / \mathrm{min}$ with applied bias assuring the extraction of thermally generated carriers. The dark currents were measured without any initial light excitation.

Carrier mobility measurements were performed by the CELIV (Charge Extraction by Linearly Increasing Voltage) method [8]. Carriers were extracted from the sample by an applied in reverse direction triangular voltage pulse with a constant increase rate. The mobility was evaluated from the position of a characteristic maximum, as described in more detail in [8].

The experimental results were analysed numerically by taking into account the mobility variation according to the Gaussian Disorder Model (GDM) approximation [9] as well as carrier thermal generation from traps $[10,11]$. Such a complex analysis had made possible not only the evaluation of trap parameters, but it had also demonstrated a clear coincidence of results given by both methods, evidencing that the carrier trapping is a decisive factor in their mobility behaviour.

\section{Results and discussion}

\subsection{Device parameters and efficiency}

To test the quality of devices, an $I V$ curve of each device was measured under illumination by Air Mass (AM) 1.5 spectrum light with $100 \mathrm{~mW} / \mathrm{cm}^{2}$ incident power density. These are shown in Fig. 3. In the tested 

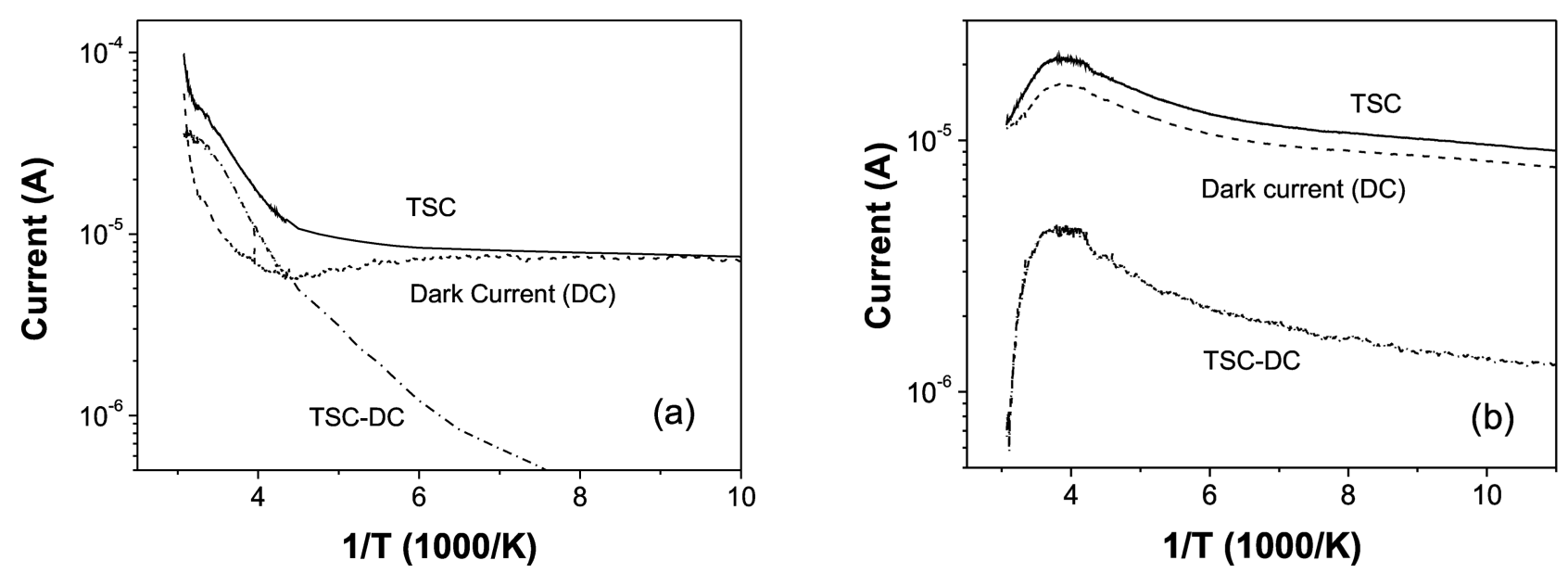

Fig. 4. Experimental Thermally Stimulated Current spectra measured after excitation (solid curves), dark currents (dashed curves), and their differences (dashed-dotted curves) in two samples $(a, b)$.

devices a solar efficiency of $3.7 \pm 0.2 \%$ was reached. The high fill factor of $68 \%$, the open circuit voltage of $634 \mathrm{mV}$, and the short circuit current of $8.6 \mathrm{~mA} / \mathrm{cm}^{2}$ demonstrate significant improvement of the device parameters as compared to the first devices produced in this layout [7]. Moreover, the high fill factor evidences that transport problems are of minor importance. Nevertheless, to have a clearer insight, we have investigated carrier transport properties in more detail as described below.

\subsection{Identification of carrier trapping states}

The experimental TSC spectra are presented in Fig. 4(a,b) for two devices fabricated on the same glass substrate. Despite the fact that the devices were produced simultaneously, their current spectra do not coincide quantitatively, indicating that even small technological variations might result in significant deviations of device properties. Nevertheless, upon subtraction of the dark current from the TSCs measured after the preexcitation by white light at liquid nitrogen temperature, a qualitative coincidence of the results is clearly seen. In both cases characteristic TSC maxima, though being different in detail, appear in the spectra. Appearance of the current maxima cannot be explained by carrier mobility behaviour within the GDM model, which foresees only a mobility increase with temperature. An exception might happen in systems with two perfectly blocking electrodes. In this case current maxima can appear when all carriers become extracted from the device because of the growing mobility [12]. Nevertheless, in such case maxima positions should demonstrate an expressed dependence on the heating rate and applied electric field [12], and we did not observe such behaviour. Moreover, in our samples a current growth took place after the maxima were passed, indicating that the TSC maxima were caused by the emptying of traps.

Therefore the obtained resulting curves were modelled by taking into account the thermal generation of carriers from trap states as well as the carrier mobility increase described in detail in [6]. The results for the same samples are presented in Fig. 5(a,b). The thermal activation energy values of the traps were coinciding well within the range of experimental errors: they were equal to $0.18 \pm 0.02 \mathrm{eV}$ in all the samples. The density of traps was evaluated by integrating the current dependence over time. It is found to range between $10^{20}$ to some $10^{21} \mathrm{~cm}^{-3}$. Such a high density of traps implies that they could take active part in carrier transport, acting as transport states and mediating the carrier hopping. A qualitatively similar effect, i. e., impurity band transport, is well-known in crystalline semiconductors. Characteristically, in samples of lower conductivity the trap density was also significantly lower $[4,6]$, confirming qualitatively the above conclusion. The coinciding activation energy of the traps in different samples and their high density implies that they are most probably not caused by some dopants, e. g., oxygen, but are rather related to the material structure itself.

\subsection{Mobility dependences}

Carrier mobility data could be compared by two different methods: TSCs and direct mobility measurements, presented in Fig. 6. In GDM the charge transport in disordered organic conductors is supposed to proceed by means of hopping in a Gaussian site-energy distribution, reflecting the energetic spread in the charge trans- 

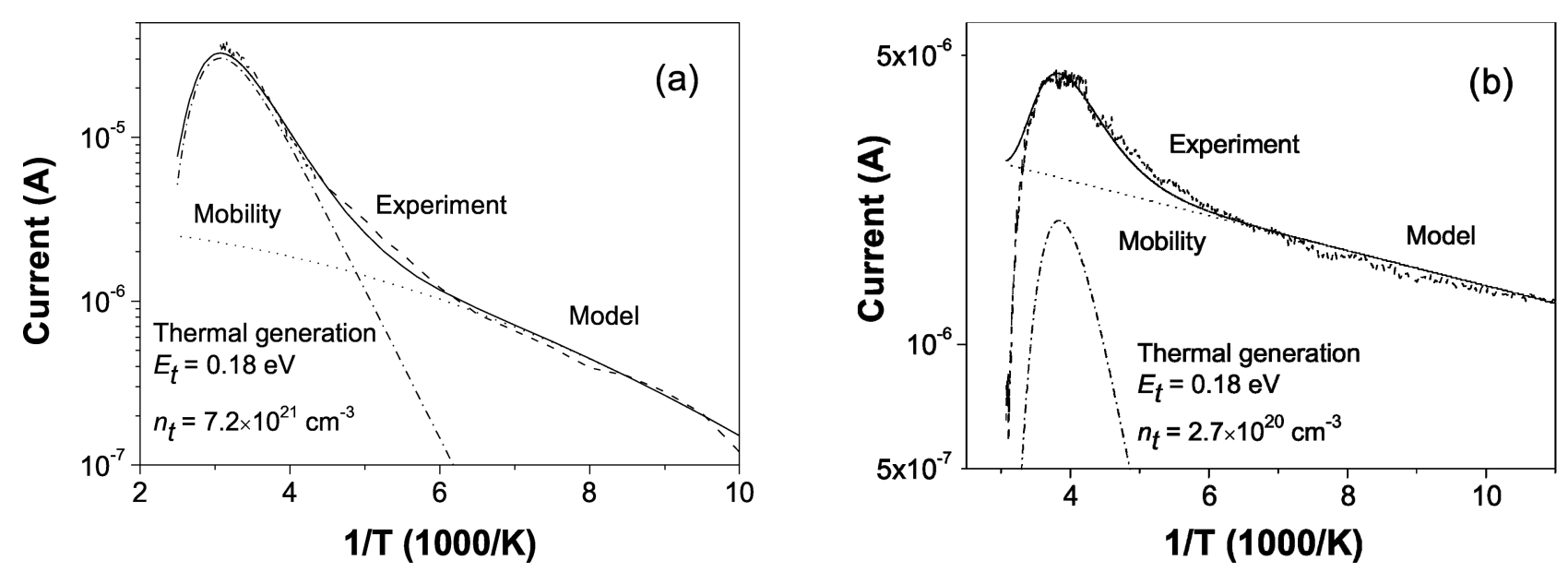

Fig. 5. Experimental dependences (dashed curves) and their modelling (solid curves) by taking into account the carrier mobility variation (dotted lines) and the thermal generation of carriers (dash-dotted curves) in the same two samples as shown in Fig. 4(a,b).

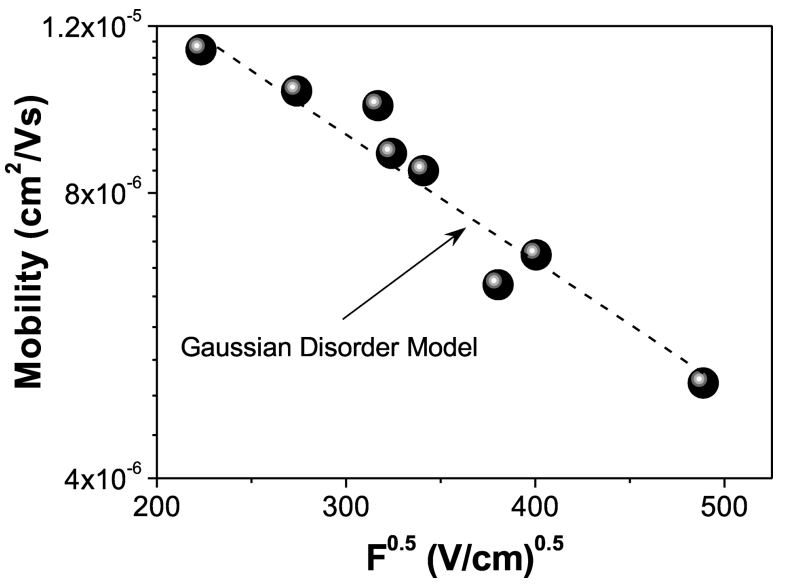

Fig. 6. Mobility dependence versus applied electric field strength and its fitting by the Gaussian Disorder Model.

porting levels of chain segments due to fluctuation in conjugation lengths and structural disorder [9]:

$$
\begin{aligned}
\mu(F, T)= & \mu_{\infty} \exp \left[\left(-\frac{2 \sigma}{3 k T}\right)^{2}\right] \\
& \times \exp \left\{C\left[\left(\frac{\sigma}{k T}\right)^{2}-\Sigma^{2}\right] \sqrt{F}\right\} .
\end{aligned}
$$

This equation was derived from Monte Carlo simulations of the hopping processes of charge carriers in a material with transport states described by Gaussian distribution functions. In Eq. (1) $F$ is the electrical field strength, $k$ is the Boltzmann's constant, $\sigma$ is the width of the energetic disorder of the film, and $\Sigma$ is the temperature independent parameter related to positional disorder. $\mu_{\infty}$ is the high temperature limit of the mobility and $C$ is a specific parameter that is obtained from the simulations as $C=2.9 \cdot 10^{-4}(\mathrm{~cm} / \mathrm{V})^{0.5}$ [9]. Fitting of the TSCs by GDM, shown in Fig 5(a,b) by dotted lines, has given the following values: the positional disorder parameter $\Sigma$ is found to be equal to 4.5 , and the parameter of energetic disorder $\sigma$ ranges from 0.028 to $0.042 \mathrm{eV}$. The high-temperature mobility limit $\mu_{\bar{\infty}}$ was found to be (1.5-1.9) $10^{-3} \mathrm{~cm}^{2} /(\mathrm{V} \mathrm{s})$, meanwhile the coefficient $C$ was $(4.5-6) \cdot 10^{-4}(\mathrm{~cm} / \mathrm{V})^{0.5}$.

The so-called negative mobility dependence was observed in Fig. 6. Such a behaviour is usually observed in materials in which the carrier transport is governed by the positional disorder, rather than the energetic one. Similar behaviour was many times observed in different disordered materials, e. g., molecularly doped polymers, molecular glasses, etc. In polymers, the negative mobility behaviour was first evidenced by the CELIV method in P3HT in [13] and P3OT in [14]. The prevailing role of positional disorder is quite logical in the investigated solar cells with bulk heterojunction structure. The experimentally measured dependence in Fig. 6 was also fitted by the GDM with the following fitting parameters: $\Sigma=4.5, \sigma=0.045 \mathrm{eV}$, $\mu_{\infty}=9.5 \cdot 10^{-4} \mathrm{~cm}^{2} /(\mathrm{V} \mathrm{s}), C=1.8 \cdot 10^{-4}(\mathrm{~cm} / \mathrm{V})^{0.5}$. It can be seen that the fitting parameters of experimental data obtained by completely different methods coincide quite well. This evidences that carrier trapping is a decisive factor in their mobility behaviour.

\section{Summary and conclusions}

We have investigated carrier transport and trapping in blends of 6:5 wt. P3HT:PCBM that are important for the development of organic solar cells. The devices with an inverted layer sequence and energy conversion 
efficiency of $3.7 \%$ were analysed. We demonstrate that, though the fill factor of the $I V$ characteristics is as high as $68 \%$, the carrier trapping is effectively involved in the transport phenomena. The evaluated trapping state activation energy was about $0.18 \mathrm{eV}$ while their density was up to $10^{20}-7 \cdot 10^{21} \mathrm{~cm}^{-3}$. At such a high density these states presumably act as transport states, governing the carrier mobility behaviour. The results were analysed by taking into account the mobility variation according to the Gaussian disorder model as well as the carrier thermal generation from traps. The mobility parameters obtained by both methods demonstrate good coincidence.

\section{Acknowledgement}

The work was performed within the OrgaPVNet project of the EU's Sixth Framework Programme.

\section{References}

[1] Y. Kim, S. Cook, S.M. Tuladhar, S.A. Choulis, J. Nelson, J.R. Durrant, D.D.C. Bradley, M. Giles, I. Mcculloch, C.S. Ha, and M. Ree, A strong regioregularity effect in self-organizing conjugated polymer films and high-efficiency polythiophene: Fullerene solar cells, Nature Mater. 5(3), 197-203 (2006).

[2] R. Pacios, A.J. Chatten, K. Kawano, J.R. Durrant, D.D.C. Bradley, and J. Nelson, Effects of photo-oxidation on the performance of poly[2methoxy-5-(3',7'-dimethyloctyloxy)-1,4-phenylene vinylene]:[6,6]-phenyl $\mathrm{C}_{61}$-butyric acid methyl ester solar cells, Adv. Funct. Mater. 16(16), 2117-2126 (2006).

[3] T. Offermans, S.C.J. Meskers, and R.A.J. Janssen, Electro-optical studies on MDMO-PPV:PCBM bulkheterojunction solar cells on the millisecond time scale: Trapped carriers, Org. Electron. 7, 213-221 (2006).

[4] V. Kažukauskas, V. Čyras, M. Pranaitis, A. Apostoluk, L. Rocha, L. Sicot, P. Raimond, and C. Sentein, Influence of polar molecular chain orientation on optical and carrier transport properties of polymer blends, Org. Electron. 8, 21-28 (2007).

[5] C. Renaud, C.H. Huang, M. Zemmouri, P. Le Rendu, and T.P. Nguyen, Study of traps in polydiacetylene based devices using TSC technique, Eur. Phys. J. Appl. Phys. 36, 215-218 (2006).

[6] V. Kažukauskas, Investigation of carrier transport and trapping by oxygen-related defects in MEH-PPV diodes, Semicond. Sci. Technol. 19(12), 1373-1380 (2004).

[7] M. Glatthaar, M. Niggemann, B. Zimmermann, P. Lewer, M. Riede, A. Hinsch, and J. Luther, Organic solar cells using inverted layer sequence, Thin Solid Films 491(1-2), 298-300 (2005).

[8] G. Juška, K. Arlauskas, M. Viliūnas, and J. Kočka, Extraction current transients: New method of study of charge transport in microcrystalline silicon, Phys. Rev. Lett. 84, 4946-4949 (2000).

[9] H. Baessler, Charge transport in disordered organic photoconductors. A Monte Carlo simulation study, Phys. Status Solidi B 175, 15-56 (1993).

[10] J.G. Simmons and G.W. Taylor, High-field isothermal currents and thermally stimulated currents in insulators having discrete trapping levels, Phys. Rev. B 5, 16191629 (1972).

[11] G. Kavaliauskienè, V. Kažukauskas, V. Rinkevičius, J. Storasta, J.V. Vaitkus, R. Bates, V. O'Shea, and K.M. Smith, Thermally stimulated currents in semiinsulating GaAs Schottky diodes and their simulation, Appl. Phys. A 69, 415-420 (1999).

[12] I. Chen, Theory of thermally stimulated current in hopping systems, J. Appl. Phys. 47(7), 2988-2994 (1976).

[13] A.J. Mozer, N.S. Sariciftci, A. Pivrikas, R. Österbacka, G. Juška, L. Brassat, and H. Bässler, Charge carrier mobility in regioregular poly(3-hexylthiophene) probed by transient conductivity techniques: A comparative study, Phys. Rev. B 71, 035214 (2005).

[14] V. Kažukauskas, M. Pranaitis, L. Sicot, and F. Kajzar, Negative mobility dependence in different regioregular polythiophenes revealed by the charge extraction by linearly increasing voltage method, Mol. Cryst. Liq. Cryst. 447, 459-471 (2006). 


\title{
KRŪVININKŲ GAUDYKLĖS KAIP KRŪVIO PERNAŠOS BŪSENOS ERDVINĖSE İVIRIATARPĖSE P3HT:PCBM SAULĖS ELEMENTŲ STRUKTŪROSE
}

\author{
V. Kažukauskas ${ }^{a}$, M. Pranaitis ${ }^{a}$, A. Arlauskas ${ }^{a}$, M. Glatthaar ${ }^{b}$, A. Hinsch ${ }^{\text {b }}$

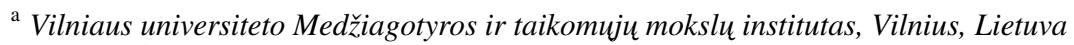 \\ ${ }^{\mathrm{b}}$ Fraunhoferio saules energijos institutas, Fraiburgas, Vokietija
}

\begin{abstract}
Santrauka
Organinių medžiagų, skirtų optoelektronikai, makroskopinius parametrus iš esmès lemia krūvininkų pernašos savybès, tokiu būdu paveikdamos ir kuriamų prietaisų funkcionalumą bei efektyvumą. Todèl organinių medžiagų inžinerija bei prietaisų kūrimo ir tobulinimo perspektyvos priklauso nuo fundamentinių žinių, sukauptų tiriant krūvio pernašą ir su ja susijusius reiškinius. Buvo tiriama krūvininkų pernaša ir pagavimas P3HT:PCBM aktyviajame mišinyje, skirtame organiniu fotovoltiniu elementu gamybai. Tirtųjų struktūru energijos konversijos efektyvumas siekė 3,7 proc., o apšviestų 1,5 AM spektro šviesa elementų voltamperinių charakteris-
\end{abstract}

tikų užpildos faktorius viršijo 68 proc. Nustatėme, jog, nepaisant šiu palyginti neblogų kiekybinių rodiklių, krūvininkų pernašą stipriai veikia ju pagavimas. Ivertinus gaudyklių parametrus, gauta aktyvacijos energija, siekianti $0,18 \mathrm{eV}$, o gaudykliu tankis buvo $10^{20}$ $7 \cdot 10^{21} \mathrm{~cm}^{-3}$. Esant tokiam dideliam šių būsenų tankiui, jos gali elgtis kaip krūvio pernašos būsenos, lemiančios krūvininkų judrị. Srovès kitimas bandiniuose buvo analizuojamas atsižvelgiant ir i krūvininkų šiluminę aktyvaciją iš gaudyklių, ir i jų judrio kitimą, nusakomą Gauso netvarkos modeliu. Paaiškèjo, jog judrio parametrai, gauti ir analizuojant šiluma skatinamuju ų srovių priklausomybes, ir tiesiogiai matuojant judrị, sutampa. 